\title{
SUBSURFACE GAS GENERATION AT A LANDFILL IN JOHANNESBURG
}

\author{
Shaazia Bhailall ${ }^{1}$, Stuart Piketh ${ }^{1}$, Neville Smith ${ }^{2}$, and Jean Bogner ${ }^{3}$, \\ ${ }^{1}$ Climatology Research Group, Department of Geography Archaeology and Environmental Studies, University of the \\ Witwatersrand, Johannesburg, 2050, South Africa, shaazia@crg.wits.ac.za, stuart@crg.wits.ac.za \\ 2 PIKITUP, Johannesburg, South Africa \\ ${ }^{3}$ Landfills + Inc, Wheaton, Illinois, United States
}

\begin{abstract}
Landfill gas (LFG) consisting of $50-60 \% \mathrm{v} / \mathrm{v} \mathrm{CH}_{4}$ contributes to global greenhouse gas emissions as well as to local air pollution and nuisance odours; in addition, the uncontrolled subsurface migration of LFG can pose an explosion hazard. LFG is explosive mostly due to its $\mathrm{CH}_{4}$ content. $\mathrm{CH}_{4}$ is explosive at concentrations of $5-15 \%$ in air. Venting of the gas to the atmosphere prevents any explosion risk; however, the concern lies with the lateral migration of $\mathrm{CH}_{4}$ through soil and along cracks and its subsequent accumulation. This highlights the importance of subsurface LFG monitoring. In this study, subsurface LFG generation is measured at a solid waste disposal site situated approximately $20 \mathrm{~km}$ west of Johannesburg. The results of three first-order kinetic models (to estimate LFG generation) for the site are compared. The three models are LandGEM, GasSim and the IPCC model contained in the 2006 UNFCCC 2006 National Inventory Guidelines for waste. High LFG concentrations are recorded along the northern boundary of the site (exceeding 60\% v/v). Modelled LFG generation simulations are slightly higher from LandGEM whilst the IPCC Waste Model predicts the lowest concentrations.
\end{abstract}

Keywords: Landfill gas, methane, carbon dioxide, subsurface probes.

\section{Introduction}

1.1. $\mathrm{CH}_{4}$ is a radiatively active trace gas (Cicerone and Oremland, 1988; Dlugokencky et al., 1998; Shipham et al., 1998). The atmospheric concentration of $\mathrm{CH}_{4}$ during pre-industrial times is estimated at $0.7 \mathrm{ppm}$, whereas the concentration in 2005 was $1.774 \pm 1.8 \mathrm{ppm}$ (IPCC, 2007). There are a number of contributors to the increasing amount of $\mathrm{CH}_{4}$ in the atmosphere and landfills are among the largest of these sources (Hein et al., 1997; Houweling et al., 1999).

In South Africa, environmental regulations governing waste disposal are set out in the Minimum Requirements for Waste Disposal, released by Department of Water Affairs and Forestry (DWAF) in 1998 (Morris, 2001). These documents provide a set of standards and criteria for the selection, investigation, design, preparation, operation, closure and monitoring of landfill sites (DWAF, 1998; Morris, 2001). According to the Minimum Requirements waste is classified into two categories namely general $(G)$ and hazardous $(H)$. The eventual size of a landfill is calculated from the maximum rate of deposition expected at the site (from the opening year of the landfill up to and including its year of closure). Once the maximum rate of deposition is calculated, landfills are categorised into four sizes namely communal (C), small (S), medium (M) and large (L) (DWAF, 1998).

The water balance at the landfill is based on the potential for significant leachate generation to occur at the site and is affected by rainfall, evaporation, moisture content of waste and water infiltrating the waste body (DWAF, 1998). If it is positive for less than one year in five, it is assumed that no significant leachate generation will occur at the site and the site is classified as $\mathrm{B}^{-}$(sporadic leachate generation likely). If $B$ is positive for more than one year, it is assumed that significant leachate generation will occur at the site and the site is classified as $\mathrm{B}^{+}$(significant leachate generation likely) (DWAF, 1998; Morris, 2001 ). There are different requirements for the design and operation of a landfill depending on the classification of the landfill.

According to the Minimum Requirements, gas generation must be monitored at three monthly intervals. At present only a few gas management systems (where LFG is collected and utilised) exist in South Africa. Passive venting to the atmosphere and flaring are the most common practices (Bogner and Lee, 2004). Previous studies on landfills in South Africa have focused on the polluting potential of landfills and seasonal variations in waste composition and its effect on LFG 
production. There is a need to estimate annual emissions from landfills in South Africa to aid in the assessment of the possibility of gas extraction systems for landfills. This will allow the country to exploit economic resources available under the Kyoto Protocol through the Clean Development Mechanism (CDM) and possibly reduce national $\mathrm{CH}_{4}$ emissions.

In this study, LFG generation and emission rates from landfills in South Africa have been evaluated by analysing subsurface LFG data and estimating emissions using theoretical models namely the USEPA's LandGEM, the UK developed GasSim and the IPCC Waste Model 2006. LFG generation was estimated at a landfill in Johannesburg, denoted Landfill B.

\section{Materials and methods}

\subsection{Site description}

The site is located approximately $20 \mathrm{~km}$ to the west of Johannesburg and services the western part of the Greater Johannesburg Metro and the northern parts of Soweto. The landfill covers 44 hectares and surrounding land is mainly used for industrial and mining purposes. The landfill accepts approximately 30000 tonnes of waste a month and is divided into two cells. Cell 1 is closed and currently not operational. The site is generally in a good condition and well managed. The cell does not have a final cap although most of the surface is covered with a temporary thin layer of soil (mostly builders rubble).

A number of subsurface probes were placed on the boundary of the landfill site. A survey conducted in September 2008 highlighted the need for the design of the probes to be changed as most probes at the sites were blocked or damaged. The probes are perforated allowing for gas movement and range in depth from 1-3m along the perimeter of the site (Figure 1).

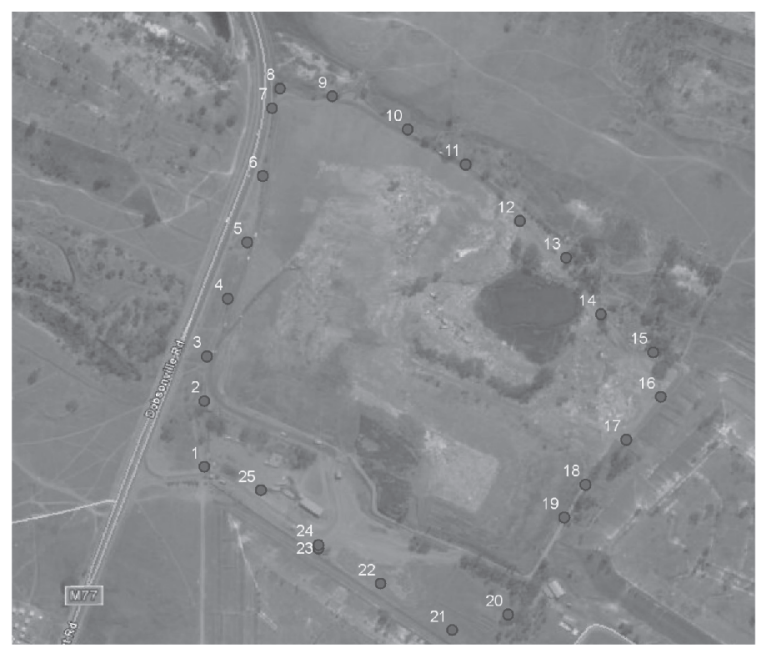

Figure 1. Location of subsurface gas probes at Landfill A. There are 25 probes located along the landfill boundary.

Direct readings of gas concentrations $\left(\mathrm{CH}_{4}, \mathrm{CO}_{2}\right.$ $\mathrm{O}_{2}, \mathrm{H}_{2} \mathrm{~S}$ and $\mathrm{CO}$ ) are taken using the GA2000 hand-held infrared gas analyser. Sampling was conducted in September 2009.

The spatial distributions of the LFG from the landfills are presented in contour plots. It is important to recognize that the gas concentrations are only correct at the probe. Other areas are interpolated values calculated using a gridding function feature on the program, Surfer, a gridbased contour program.

\subsection{Landfill gas estimation models used}

The amount of $\mathrm{CH}_{4}$ emitted from the surface of the landfill requires an estimate of the $\mathrm{CH}_{4}$ potential of the waste (Peer et al., 1993). The development of LFG models started in the 1970's. These models require knowledge on mechanisms controlling LFG production and describe these factors with simplified mathematical equations (Cossu et al., 1996). A model chosen for LFG analysis should be based on the availability of data and the output required. The majority of LFG estimation models follow first order kinetics (Cossu et al., 1996) where the amount of product is always proportional to the amount of reactive material (IPCC, 2006). In a multi-phase first order model, waste fractions are divided into slow (wood and wood products), moderate (paper and textiles) or fast (food and garden) decomposing materials (EMCON, 1980 Cossu et al., 1996; IPCC, 2006).

Due to variations in waste types, disposal rates, climate and operational conditions, the rate of LFG generation varies from landfill to landfill. Most LFG estimation models can account for this variability (Pitchel, 2005). Site management and local or regional climate conditions also affect the rate of LFG production (Coops et al, 1995). It is important that data is available on all these factors before an attempt is made to model LFG generation. LFG estimation models LandGEM, GasSim and the IPCC Waste Model 2006 are applied to estimate gas generation from the landfill site in this study.

The Landfill Gas Estimation Model (LandGEM) was developed by the Clean Air Technology Centre (CTC) of the United States Environmental Protection Agency (USEPA) (Pelt et al., 1998). The model is classified as a simplified deterministic model according to Cossu et al. (1996) as it uses a simplified mathematical equation to describe the 
decay of waste. It is based on a first order decomposition rate reaction. Model defaults are based on empirical data from US landfills (Alexander et al., 2005). Inventory default values are based on emission factors in the USEPA's Compilation of Air Pollutant Factors (AP-42). LandGEM determines the mass of $\mathrm{CH}_{4}$ generated using the $\mathrm{CH}_{4}$ generation capacity and the mass of annual waste deposited at the landfill since its opening.

GasSim has been developed for the UK Environmental Agency. It is a conceptual model that considers the landfill as individual cells each with their own engineering and waste composition. GasSim uses both a multi-phase model (described by van Zanten and Scheepers (1994)) and another approach based on the LandGEM model to calculate an estimate of $\mathrm{CH}_{4}$ emissions (Gregory et al., 2003). The multi-phase model utilises waste input in various categories and fractions and the detailed decomposition of the waste during the particular year of disposal.

The IPCC Waste Model 2006 is a first order multiphase model based on waste composition data. The amounts of degradable waste material (food, garden and park waste, paper and cardboard, wood, textiles) contained in the waste are entered separately. It uses a number of equations that allow total LFG to be estimated. These require accurate country specific variables (Bogner and Matthews, 2003).

\section{Results and discussion}

\subsection{Monitored subsurface LFG}

Subsurface LFG monitored at the site in September 2009 (using a hand held gas analyser GA2000 infrared gas analyser) was analysed and $\mathrm{CH}_{4}$ and $\mathrm{CO}_{2}$ fractions in LFG identified. The $\mathrm{CH}_{4}$ and $\mathrm{CO}_{2}$ generation from Landfill $A$ is given in Figure 2.

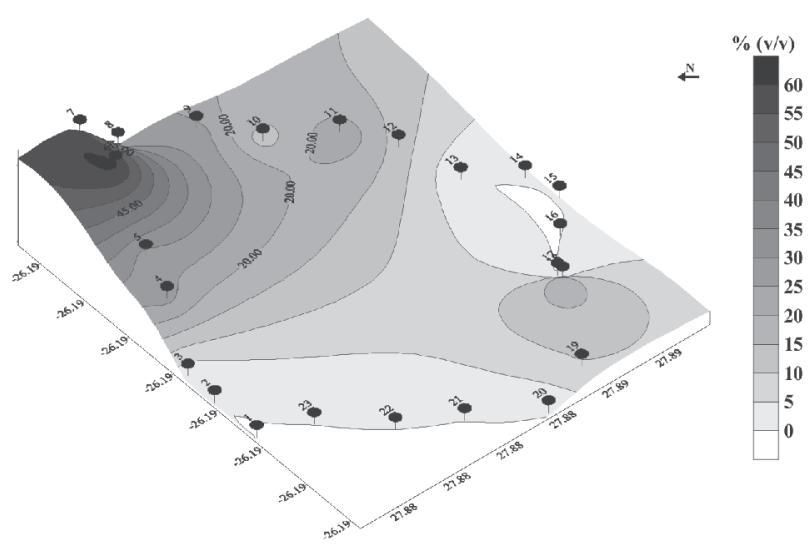

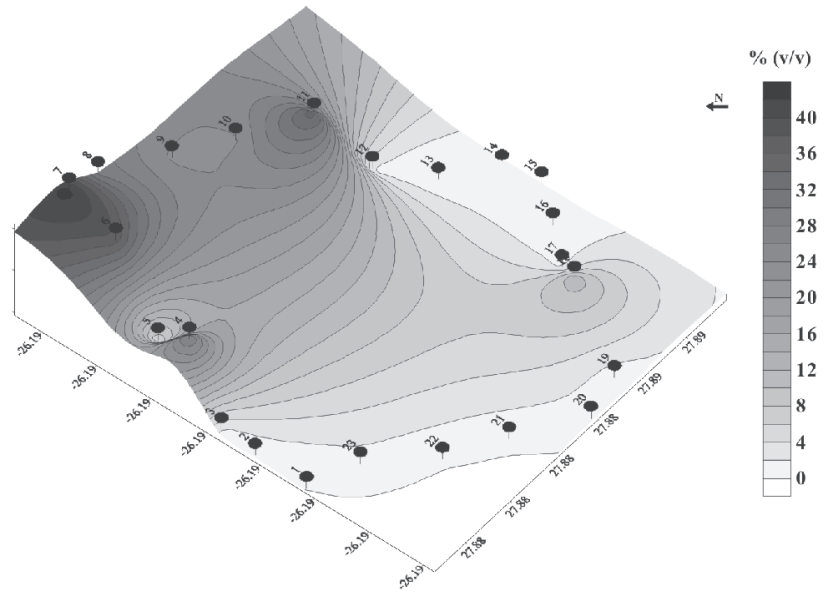

Figure 2. $\mathrm{CH}_{4}$ (top) and $\mathrm{CO}_{2}$ (bottom) generation at Landfill $\mathrm{A}$. Concentrations of $\mathrm{CH}_{4}$ exceed $60 \% \mathrm{v} / \mathrm{v}$.

$\mathrm{CH}_{4}$ generated from the landfill is fairly high with probes 6 and 7 recording concentrations exceeding $60 \% \mathrm{v} / \mathrm{v} . \mathrm{CO}_{2}$ concentrations follow a similar trend to $\mathrm{CH}_{4}$ concentrations but concentrations are lower. Highest LFG concentrations are along the northern boundary of the site. The landfill is in the methanogenic stage (demonstrated by the high concentration of $\mathrm{CH}_{4}$ and lower concentrations of $\mathrm{CO}_{2}$ ).

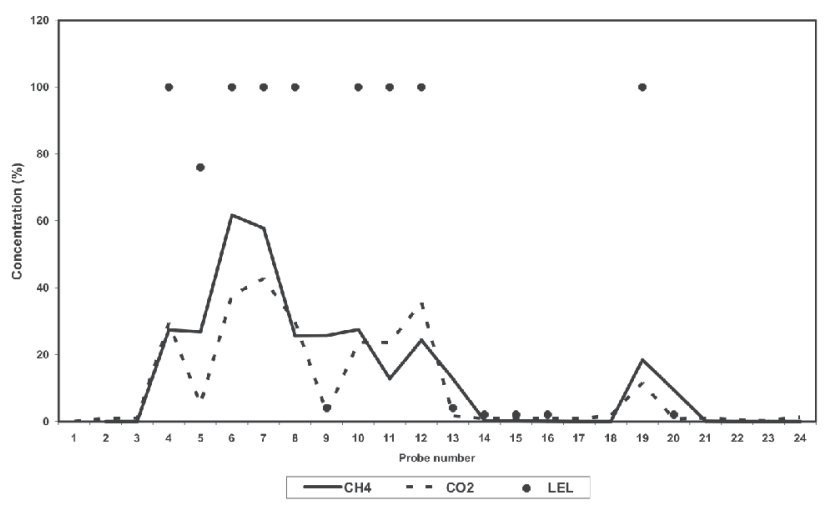

Figure 3. $\mathrm{CH}_{4}$ and $\mathrm{CO}_{2}$ concentrations at the site. Lower explosive limits (LEL \%) at some locations are above $100 \%$.

$\mathrm{CH}_{4}$ is explosive at concentrations of $5-15 \%$ in air. The lower explosive limit (LEL) at the site in some areas (probes 4,6,7,8, 10, 11, 12 and 19) exceed $100 \%$ (Figure 3 ). This highlights the importance of subsurface LFG monitoring at the site. 


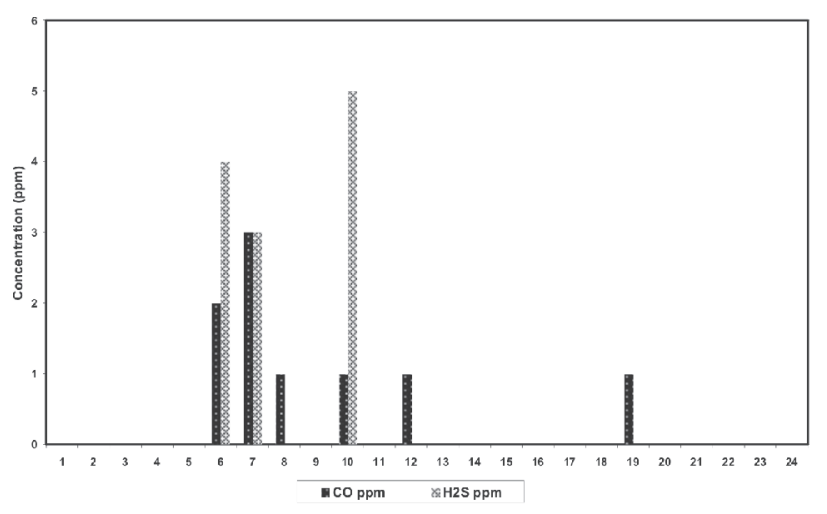

Figure 4. $\mathrm{H}_{2} \mathrm{~S}$ and $\mathrm{CO}$ concentrations at the site. $\mathrm{H}_{2} \mathrm{~S}$ peaks at $5 \mathrm{ppm}$. Concentrations in probes with no readings are below detectable limits of the instruments.

$\mathrm{H}_{2} \mathrm{~S}$ and $\mathrm{CO}$ concentrations at probes 6,7 and 10 are high, peaking at $5 \mathrm{ppm}$ at probe 10 (Figure 4). $\mathrm{H}_{2} \mathrm{~S}$ is a highly toxic gas that has serious implications for odours at the site as well as health implications (Kim, 2006).

\subsection{Modelled LFG generation}

LFG generation was modelled using monitored gas data collected between 2003 and 2006 at the site (using a hand held gas analyser GA94 infrared gas analyser). The subsurface probes were located at different points than the current probes. $\mathrm{CH}_{4}$ concentrations ranged between 5 and $50 \% \mathrm{v} / \mathrm{v}$ whilst $\mathrm{CO}_{2}$ concentrations ranged from $2-30 \%$ $\mathrm{v} / \mathrm{v}$.

LandGEM LFG generation simulations are slightly higher (due to the models inability to allow waste fractions to be used as input) whilst the IPCC Waste Model predicts the lowest concentrations (Figures 5).

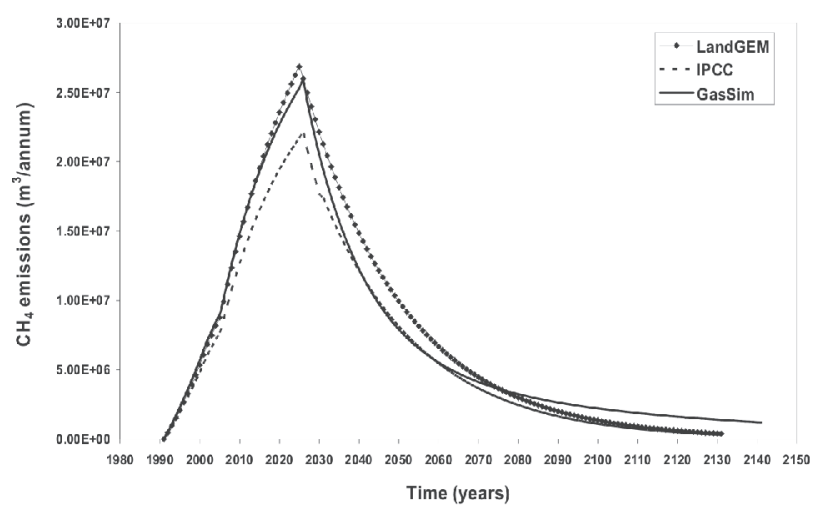

Figure 5. $\mathrm{CH}_{4}$ generation simulations by LandGEM, IPCC Waste Model and GasSim at Landfill A.
The total percentage of inert waste was subtracted from the total waste and entered into LandGEM. Hence, $70 \%$ of waste was considered to be degradable waste. All the models show an increase in LFG emissions with increasing waste deposition over time. Emissions at the site increase with time and peak in 2025/2026. LandGEM simulates peak LFG emissions during closure year (2025) of the landfill whilst GasSim and IPCC Waste Model simulate peak emissions during the year after closure. Since the modelling is based on $\mathrm{CH}_{4}$ and $\mathrm{CO}_{2}$ concentrations much lower then more recent measurements at the site it is possible that simulations (based on current fractions) will be higher.

In conclusion, the concentrations of LFG observed highlight the need for continuous monitoring of subsurface gas generation, with particular attention to the north and north-eastern sections at the site. These measurements are indicative that lateral migration of LFG could be occurring in these areas. High $\mathrm{H}_{2} \mathrm{~S}$ and $\mathrm{CO}$ concentrations recorded in these areas are of concern.

\section{Acknowledgments}

The authors would like to thank the City of Johannesburg (CoJ) and Pikitup for funding for the project and supplying site information used in this study.

\section{References}

Alexander, A., Burklin, C., and Singleton, A., 2005, 'Landfill Gas Emissions Model (LandGEM) Version 3.02 Users Guide', Eastern Research Group, Morrisville, NC.

Bogner, J.E., Matthews, E., 2003, 'Global methane emissions from landfills: new methodology and annual estimates 1980-1996', Global Biogeochemical Cycles, 17, 34:1-18.

Bogner, J.E., and Lee, C.A., 2004, 'Landfill gas recovery in South Africa: Status, issues and markets', In Proceedings of the Biennial Congress of the Institute of Waste Management of Southern Africa, WasteCon, Sun City, South Africa.

Cicerone, R.J., Oremland, R.S., 1988, 'Biogeochemical aspects of atmospheric methane', Global Biogeochemical Cycles, 2 (4): 299-327.

Coops, O., Luning, L., Oonk, H., and Weenk, A., 1995, 'Validation of landfill gas formation models', In Proceedings of the 5th International Landfill Symposuim, CISA, Cagliari, Italy.

Cossu, R., Andreottola, G., and Muntoni, A., 1996, 'Modelling landfill gas production', In T.H., Christensen, R., Cossu, and R., Stegmann, Landfilling of waste: Biogas, E \& FN Spon, London. 
Dlugokencky, E., Masarie, K., Lang, P., Tans, P., 1998, 'Continuing decline in the growth rate of the atmospheric methane burden', Nature, 393447.

DWAF (Department of Water Affairs and Forestry) South Africa, 1998, 'Minimum requirements for waste disposal by landfill', Second addition, Pretoria.

EMCON, 1980, 'Methane generation and recovery from landfills', EMCON Associates, Ann Arbor Science Publishers, Michigan.

Gregory, R.G., Attenborough,G.M., Hall, D.C., and Deed, C., 2003, 'The validation and development of an intergrated landfill gas risk assessment model GasSim', In Proceedings of the 9th International Waste Management Symposium, Sardinia, Italy.

Hein, J., Crutzen, P., Heinmann, M., 1997, 'An inverse modelling approach to investigate the global atmospheric methane cycle', Global Biogeochemical Cycles, 11:43-76.

Houweling, S., Kaminski, T., Dentener, F., Lelieveld, J., Heinmann, M., 1999, Inverse modelling of methane sources and sinks using the adjoint of a global transport model, Journal of Geophysical Research, 104:26137-26160.

IPCC (Intergovernmental Panel on Climate Change), 2006, 'Guidelines for national greenhouse gas inventories', Chapter 3 (Solid waste disposal).

IPCC (International Panel on Climate Change), Bogner, J.E., Abdelrafie, A.M., Diaz, C., Faaij, A., Gao, Q., Hashimoto, S., Mareckova, K., Pipatti, R., Zhang, T., 2007, 'Waste Management', In B. Metz, O.R. Davidson, P.R. Bosch, R. Dave, L.A. Meyer (eds), Climate Change 2007: Mitigation. Contribution of Working Group III to the Fourth Assessment Report of the Intergovernmental Panel on Climate Change, Cambridge University Press, Cambridge.

Kim, K. H., 2006, 'Emissions of reduced sulfur compounds (RSC) as a landfill gas (LFG): A comparative study of young and old landfill facilities', Atmospheric Environment, 40:6567-6578.

Morris, J.W.F., 2001, 'Effects of waste composition on landfill processes under semi-arid climatic conditions', Unpublished Ph.D. thesis, University of the Witwatersrand, Johannesburg, South Africa.

Peer R.L., Thorneloe, S.A., and Epperson, D.L., 1993, 'A comparison of methods for estimating global methane emissions from landfills', Chemosphere, 26: 387-400.

Pelt R., Thorneloe, S.A., Bass, R.L., Heaton, R.E., White, C., Blackard, A., Burklin, C., and Reisdorph, A., 1998, 'Landfill Gas Emissions Model (LandGEM) - Users manual', US Environmental Protection Agency, United States.

Pitchel, J., 2005, 'Waste management practices: Municipal, hazardous and industrial', CSR Press Taylor \& Francis Group, USA.
Shipham, M., Bartlett, K., Crill, P., Harriss, R., Blaha, D., 1998, 'Atmospheric methane measurements in central New England: An analysis of the long term trend and the seasonal and diurnal cycles', Journal of Geophysical Research, 103 (D9):10621-10630.

Van Zanten, B., and Scheepers, J.J.M., 1994, 'Modelling of landfill gas potentials', Report prepared for International Energy Agency, Expert Working Group on Landfill Gas (IEA-EWG). 